DOI: 10.19195/2300-7249.41.3.1

\author{
MAREK MACIEJEWSKI \\ ORCID: 0000-0002-5296-1394 \\ Uniwersytet Wrocławski
}

TOMASZ SCHEFFLER

ORCID: 0000-0002-5744-4863

Uniwersytet Wrocławski

\title{
Rozprawy Wiesława Kozuba-Ciembroniewicza w „Studiach nad Faszyzmem i Zbrodniami Hitlerowskimi”
}

Kolejna rocznica śmierci nieodżałowanej pamięci prof. zw. dr. hab. Wiesława Kozuba-Ciembroniewicza, historyka doktryn politycznych i prawnych z Wydziału Studiów Międzynarodowych i Politycznych Uniwersytetu Jagiellońskiego, przez kilkadziesiąt lat blisko związanego z tą renomowaną uczelnią, jest wprawdzie smutną, lecz mimo to ważną okazją, by ocalić od zapomnienia i utrwalić w świadomości środowisk akademickich wiedzę o jego licznych i cennych osiągnięciach naukowych. Wiele $\mathrm{z}$ nich zostało już zresztą $\mathrm{w}$ ostatnim czasie przypomnianych we wspomnieniach o tym uczonym Małgorzaty Kiwior-Filo oraz Joanny Sondel-Cedarmas, pełnych wyrazów uznania i sympatii dla niego ${ }^{1}$. W niniejszym artykule za cel postawiliśmy sobie omówienie bynajmniej nie całego, pokaźnego, dorobku naukowego Wiesława Kozub-Ciembroniewicza, lecz jedynie jego rozpraw publikowanych na łamach wrocławskich „Studiów nad Faszyzmem i Zbrodnia-

${ }^{1}$ M. Kiwior-Filo, Profesor Wiesław Kozub-Ciembroniewicz - wspomnienie Mistrza, „Politeja. Pismo Wydziału Studiów Międzynarodowych i Politycznych Uniwersytetu Jagiellońskiego" 2014, nr 6, s. 5 n.; eadem, In memoriam ... Profesor Wiesław Kozub-Ciembroniewicz (26 lipca 1944-13 lutego 2015), „Alma Mater. Miesięcznik Uniwersytetu Jagiellońskiego” 2015, nr 173-174, s. 49 n.; J. Sondel-Cedarmas, Wspomnienie Profesora Wiestawa Kozuba-Ciembroniewicza, „Studia nad Autorytaryzmem i Totalitaryzmem" 37, 2015, nr 1, s. 5 n. Zob. też M. Maciejewski, In memoriam... Wiesław Kozub-Ciembroniewicz (1944-2015), „Studia nad Autorytaryzmem i Totalitaryzmem" 36, 2014, nr 4, s. 5-6 (zeszyt ten ukazał się drukiem już po śmierci W. Kozuba-Ciembroniewicza w $2015 \mathrm{roku})$. 
mi Hitlerowskimi”, noszących od kilku lat główny tytuł „Studia nad Autorytaryzmem i Totalitaryzmem".

Pierwszy artykuł autorstwa tego uczonego ukazał się w tym wydawanym od 1974 roku (do 2007 roku nieprzerwanie pod redakcją prof. Karola Joncy) periodyku już w 1977 roku, a ostatni — w 2005 roku. Warto zaznaczyć, że prof. Kozub-Ciembroniewicz został w 2010 roku członkiem Komitetu Redakcyjnego wrocławskich „Studiów”, sprawując nader aktywnie swoje obowiązki w tym zakresie i zawsze chętnie służąc swoimi cennymi radami. Za konieczne uważamy przypomnienie, że już od początku lat siedemdziesiątych XX wieku w ogóle datowała się jego ożywiona współpraca naukowa $\mathrm{z}$ prof. Joncą i innymi badaczami z Wrocławia. Wiesław Kozub-Ciembroniewicz brał między innymi czynny udział $\mathrm{w}$ dużej międzynarodowej konferencji naukowej na temat faszyzmu, zorganizowanej w 1974 roku na Uniwersytecie Wrocławskim. Był aktywnym uczestnikiem i współpomysłodawcą innej międzynarodowej konferencji, zorganizowanej w 2010 roku również przez wrocławskich badaczy faszyzmu i nazizmu, a dotyczącej polskich interpretacji autorytaryzmu i totalitaryzmu. $Z$ wrocławskim ośrodkiem akademickim łączyło tego uczonego jeszcze co najmniej jedno ważne przedsięwzięcie badawcze, a mianowicie udział we wspólnym (wraz z przedstawicielami Uniwersytetu Warszawskiego i Uniwersytetu Adama Mickiewicza w Poznaniu) grancie „Prawo w totalitaryzmie. Aspekty teorii i praktyki”. Niestety prof. Kozubowi-Ciembroniewiczowi nie dane było ukończyć swych oryginalnych badań w ramach tego naukowego projektu.

Wracając do rozpraw zamieszczanych przez niego w „Studiach nad Faszyzmem i Zbrodniami Hitlerowskimi”: najpierw jako doktor, a następnie jako docent i profesor opublikował on w ciągu dwudziestu ośmiu lat w nim sporo tekstów, bo w sumie aż dwadzieścia jeden artykułów. Najwięcej z nich ukazało się jeszcze w ostatniej dekadzie tak zwanej Polski Ludowej i na początku Trzeciej Rzeczypospolitej. Należy już w tym miejscu podkreślić, że przytłaczająca większość z nich dotyczyła włoskiego faszyzmu lub zagadnień pokrewnych, w tym jego krytyki przez przeciwników dyktatury Benita Mussoliniego. Przez wiele lat w zasadzie tylko Wiesław Kozub-Ciembroniewicz zamieszczał w tym periodyku nierzadko pionierskie artykuły na ten temat, wydatnie poszerzając w ten sposób naukowy profil tego pisma. Od początku jego ukazywania wyraźnie przeważały bowiem w nim (zwłaszcza w okresie PRL) teksty o nazizmie (dawnej niekiedy określanym po prostu mianem faszyzmu) i zbrodniach hitlerowskich. Dopiero kilkanaście lat temu zaczęły we wrocławskich „Studiach” pojawiać się także innych polskich autorów artykuły o włoskim faszyzmie. Były i są to przede wszystkim rozprawy — bardziej bądź mniej obszerne — dwóch uczennic tego uczonego, wymienionych Małgorzaty Kiwior-Filo i Joanny Sondel-Cedarmas ${ }^{2}$. Należy

${ }^{2} \mathrm{Na}$ temat naukowych osiągnięć tych dwóch osób - ze szczególnym uwzględnieniem ich rozpraw habilitacyjnych — w druku w „Czasopiśmie Prawno-Historycznym” artykuł M. Maciejewski, O współczesnych badaniach krakowskich nad wtoskim faszyzmem. 
podkreślić, że to właśnie Kozub-Ciembroniewicz najwcześniej przecierał jednak we wrocławskich „Studiach” szlaki naukowych badań w tej niewątpliwie złożonej i ciekawej dziedzinie, znacznie mniej opracowanej w Polsce niż problematyka nazizmu, którą zajmowało się i nadal zajmuje o wiele więcej autorów, by wymienić tylko najbardziej znanych i cenionych, a zatem wspomnianego Karola Joncę, Franciszka Ryszkę, Czesława Madajczyka, Franciszka Połomskiego, Marię Zmierczak czy Alfreda Koniecznego. W porównaniu z nimi badacze włoskiego i innych faszyzmów (belgijskiego, holenderskiego, hiszpańskiego, portugalskiego czy skandynawskiego) pozostają wciąż w wyraźnej mniejszości ${ }^{3}$. Niektórzy z nich mieli okazję publikować wyniki swych naukowych dociekań w „Studiach nad Faszyzmem i Zbrodniami Hitlerowskimi” lub „Studiach nad Autorytaryzmem i Totalitaryzmem". Wskutek tego z czasem poszerzała się o kolejne problemy badawcze - wykraczające poza nazizm i jego zbrodniczy system państwowy — tematyka artykułów zamieszczanych w tych periodykach. Dodajmy, że na celowość publikowania na łamach wrocławskich „Studiów” tego rodzaju tekstów, mających niekiedy tylko luźny związek z wiodącymi w nich zagadnieniami naukowymi, niejednokrotnie wskazywał prof. Kozub-Ciembroniewicz i to jeszcze przed zmianą tytułu naszego pisma.

Już kilkadziesiąt lat temu Wiesław Kozub-Ciembroniewicz dał się w naszym kraju, a nieco później także za granicą poznać jako ceniony znawca ideologii, ustroju i prawa faszystowskiego oraz w ogóle problematyki autorytaryzmu i totalitaryzmu. W tych dziedzinach badawczych stał się niekwestionowanym autorytetem intelektualnym, wykazując się rozległą erudycją i dążeniem do syntetycznych sądów naukowych. Niezbicie świadczą o tym nie tylko jego artykuły i inne drobniejsze opracowania (publikowane między innymi w „Studiach nad Faszyzmem i Zbrodniami Hitlerowskimi"), lecz także, a nawet przede wszystkim monografie książkowe, których nie będziemy omawiać w tym tekście ${ }^{4}$. Prócz Kozuba-Ciembroniewicza i jego dwóch uczennic faszyzm włoski wzięło dotychczas w Polsce na swój warsztat badawczy jeszcze tylko kilku uczonych, a wśród nich Jerzy W. Borejsza, Marek Bankowicz, Stanisław Sierpowski i Piotr Podemski oraz tylko częściowo wspomniany Franciszek Ryszka. Nie będzie przesady w twierdze-

${ }^{3}$ Ostatnio lukę w polskiej literaturze w odniesieniu do niewłoskiego faszyzmu przynajmniej częściowo wypełnił A. Wielomski w monografii książkowej Faszyzmy łacińskie. Sen o rewolucji innej niż w Rosji i Niemczech, Biała Podlaska-Warszawa 2011. Już nie najgorzej przedstawia się w polskiej literaturze kwestia omówienia faszyzmu hiszpańskiego, także między innymi dzięki publikacjom A. Wielomskiego. Odsyłamy do jego książki Hiszpania Franco. Źródta i istota doktryny politycznej, Biała Podlaska 2006. Zob. też J. Bartyzel, ,Umierać, ale powoli”. O monarchistycznej i katolickiej kontrrewolucji w krajach romańskich 1815-2000, Kraków 2002.

4 Chodzi o takie książki, jak Doktryny włoskiego faszyzmu i antyfaszyzmu w latach 1922-1939 (Kraków 1992), Dyktatury i tyranie. Szkice o niedemokratycznej władzy (Kraków 2007, wspólnie z M. Bankowiczem), Doktryna i system Włoch faszystowskich na tle porównawczym (Kraków 2011). W. Kozub-Ciembroniewicz był także współautorem i współredaktorem opracowania zbiorowego Totalitaryzmy XX wieku. Idee — instytucje - interpretacje (Kraków 2010). 
niu, że publikacje Kozuba-Ciembroniewicza na temat faszyzmu w Italii zasługują w tym kontekście na wysoką ocenę merytoryczną, między innymi ze względu na wielostronne potraktowanie przez niego tej problematyki, a zwłaszcza na jej ujmowanie w aspektach doktrynalnych i ustrojowo-prawnych, a nie tylko historyczno-politologicznych, jak czyni to większość nielicznego zresztą grona polskich autorów zajmujących się owymi zagadnieniami. Pokaźny wkład tego uczonego w rozwój w Polsce rzeczonych badań dobitnie potwierdzają rezultaty jego intelektualnych poszukiwań i dociekań prezentowane na łamach „Studiów nad Faszyzmem i Zbrodniami Hitlerowskimi”. Warto podkreślić, że Wiesław Kozub-Ciembroniewicz znalazł się (oprócz między innymi K. Joncy czy M. Maciejewskiego) w grupie autorów najczęściej zamieszczających artykuły w tym periodyku. W tym sensie współtworzył on przez co najmniej kilkanaście lat treść wrocławskich „Studiów”, zawsze ochoczo przystając na propozycje napisania do nich kolejnego tekstu ${ }^{5}$. Jego publikacje w tym piśmie naukowym (i nie tylko w nim) z reguły odznaczały się syntetycznym ujęciem omawianej problematyki i zwartym wywodem. Kozub-Ciembroniewicz wystrzegał się pisania rozwlekłych, sztucznie „rozdętych” objętościowo artykułów, preferując krótkie i zwięzłe formy twórczości naukowej o jasno postawionych tezach badawczych i precyzyjnie wysnutych wnioskach.

Jak już wzmiankowaliśmy, wśród jego tekstów we wrocławskich „Studiach” wyraźnie przeważają artykuły dotyczące samego faszyzmu w Italii. Od nich rozpoczniemy zatem omawianie odnośnego dorobku naukowego prof. Kozuba-Ciembroniewicza. Jego autorstwa artykuły o faszyzmie można podzielić na kilka grup tematycznych. W swych pierwszych opracowaniach na łamach wrocławskich „Studiów” jeszcze z lat siedemdziesiątych ubiegłego stulecia podjął się on zadania prezentacji ideologicznych i ustrojowych podstaw państwa faszystowskiego na Półwyspie Apenińskim, by następnie zająć się kwestią funkcji politycznych doktryny faszyzmu, problematyką budowy systemu korporacyjnego pod rządami Mussoliniego i jego akolitów oraz stosunkiem faszystów do Żydów. Swoją intelektualną przygodę ze „Studiami nad Faszyzmem i Zbrodniami Hitlerowskimi” Wiesław Kozub-Ciembroniewicz rozpoczął zatem od omawiania w nich bardziej ogólnych, wprowadzających kwestii badawczych, przygotowując w ten sposób Czytelnika do lektury kolejnych artykułów jego autorstwa, traktujących już o bardziej szczegółowych (wycinkowych) kwestiach. W latach osiemdziesiątych i dziewięćdziesiątych skierował on bowiem zainteresowania naukowe przede wszystkim na zagadnienia składające się w swych fragmentach na doktrynalne oblicze włoskiego faszyzmu, poddając naukowej analizie koncepcje polityczne jego prominentnych ideologów: Benita Mussoliniego, Giovanniego Gentile, Guida Bortolotto, Sergia

5 Wiadomo nam, że W. Kozub-Ciembroniewicz darzył ogromnym szacunkiem założyciela i wieloletniego redaktora naczelnego „Studiów nad Faszyzmem i Zbrodniami Hitlerowskimi” (dalej: SnFiZH) - prof. K. Joncę — chętnie współpracując z nim w sprawach naukowych i organizacyjnych. 
Panunzio, Gioacchina Volpego i Alfreda Rocco. W ten sposób znacznie przybliżył polskiemu czytelnikowi raczej mało — jak można przypuszczać — wcześniej znane mu sylwetki intelektualne kilku twórców doktryny faszystowskiej w Italii oraz w ogóle jej założenia i ich realizację w czasach dyktatury Mussoliniego, wyrastając na czołowego w naszym kraju znawcę tamtejszej idolatrii i statolatrii. Należy zaznaczyć, że w tamtym okresie nie ukazały się jeszcze w Polsce przekłady kilku cennych zagranicznych książek dotyczących wskazanej problematyki ${ }^{6}$. Ostatnią grupę artykułów Kozuba-Ciembroniewicza na łamach wrocławskich „Studiów” tworzą teksty mające już raczej luźny związek z jego głównymi zainteresowaniami włoskim faszyzmem, choć ogólnie dotyczące autorytaryzmu i totalitaryzmu oraz interpretacji tych systemów politycznych.

Pierwszym opublikowanym w „Studiach nad Faszyzmem i Zbrodniami Hitlerowskimi” artykułem Wiesława Kozuba-Ciembroniewicza (noszącego wtedy tylko jednoczłonowe nazwisko Kozub) był krótki tekst o podstawach ideologicznych włoskiego faszyzmu. Był on przygotowanym do druku referatem tego uczonego, wygłoszonym na wspomnianej międzynarodowej konferencji na temat teorii i praktyki faszyzmu w Europie (1974). Autor postawił w nim kilka ważnych tez naukowych, starając się je udowodnić na wybranych przykładach. W jego przekonaniu ideologia faszystowska rozwinęła się później niż sama organizacja faszystowska i kształtowała się pod wpływem wydarzeń politycznych rozgrywających się we Włoszech jeszcze przed marszem na Rzym bojówkarzy Mussoliniego (1922). Należy jednak zaznaczyć, że podstawowe założenia tej doktryny zostały już zawarte w programie partii faszystowskiej z 1919 roku. Niewątpliwie pełniej rozwinęła się ona dopiero po objęciu urzędu premiera przez Duce, a zwłaszcza od około połowy lat dwudziestych XX wieku, kiedy wyraźnie zaczęła krzepnąć dyktatura faszystowska po zabójstwie posła Giacoma Mateottiego. To dopiero wtedy zaczęły powstawać pierwsze opracowania faszystowskiej doktryny i filozofii politycznej ${ }^{7}$. Kozub zaliczył do nich między innymi rozprawy takich intelektualistów lub polityków, jak Giovanni Gentile, Carlo Costamagna i Guido Bortolotto oraz sam Mussolini. Wraz z pojawieniem się w publicznym obiegu pierwszych ideowych uzasadnień faszyzmu zaczęły się zdaniem krakowskiego badacza poszukiwania w kręgach jego teoretyków doktrynalnych inspiracji i źródeł tej raczej nieskomplikowanej i niezbyt oryginalnej doktryny. Faszyści odnajdywali je w koncepcji dyktatury Niccolò Machiavellego, elitaryzmie Vilfreda Pareto, nacjonalizmie Enrica Corradiniego, prefaszyzmie Gabriela d'Annunzio i jego rządach w Fiume po

${ }^{6}$ Mamy na myśli między innymi książki P. Foro, Włochy faszystowskie (przeł. K. Jokeš, Kraków 2008), E. Gentile, Początki ideologii faszystowskiej (1918-1925) (przeł. B. Orłowski, Warszawa 2011), G. Hägga, Mussolini. Butny faszysta (przeł. W. Łygaś, Warszawa 2015). Wywody o włoskim faszyzmie zawierają ponadto książki R. Eatwella, Faszyzm. Historia (przeł. J. Parzewski, Poznań 1999), W. Laqueura, Faszyzm wczoraj - dziś - jutro (przeł. A. Drzewicki, Warszawa 1998) i R.O. Paxtona, Anatomia faszyzmu (przeł. P. Bandel, Poznań 2005).

7 W. Kozub, Podstawy ideologiczne włoskiego faszyzmu, SnFiZH 3, 1977, s. 280. 
pierwszej wojnie światowej czy w dziewiętnastowiecznej ideologii (G. Garibaldi i G. Mazzini) walki Włochów o niepodległość i własne, zjednoczone państwo (Risorgimento). Kozub nie wspomniał w tym artykule (uczynił to w innym tekście) o wpływie na doktrynalne oblicze faszyzmu filozofii państwa Georga Friedricha Wilhelma Hegla. Jak wynika nie tylko z publikacji Kozuba-Ciembroniewicza, faszyści w Italii podnieśli bowiem niemal do rangi absolutu instytucję państwa, opracowując założenia ustroju totalitarnego (totalnego). Artykuł z 1977 roku można potraktować jako zapowiedź — jeszcze skromną — kolejnych tekstów krakowskiego badacza dotyczących faszyzmu na Półwyspie Apenińskim.

Bardziej obszerny od wspomnianego był kolejny zamieszczony tekst jego autorstwa z 1981 roku. Zawierał on już bardziej pogłębioną analizę doktrynalno-ustrojową faszystowskich Włoch w latach 1925-1939. Wiesław Kozub skoncentrował się w tym artykule na omówieniu następujących kwestii badawczych: władzy Mussoliniego jako charyzmatycznego przywódcy (Duce), znaczenia i roli Narodowej Partii Faszystowskiej, cech władzy unitarnej, istoty państwa totalnego oraz miejsca w systemie faszystowskim instytucji syndykatów i korporacji. W wymienionych elementach składowych ustroju faszystowskiego - wzbogaconych o elementy z reguły nachalnie uprawianej propagandy — trafnie upatrywał jego organizacyjną i funkcjonalną kwintesencję. $Z$ wywodów Kozuba wyłania się dynamiczne oblicze włoskiego faszyzmu jako systemu politycznego w okresie jego rozkwitu do początku lat czterdziestych XX wieku, działającego na zasadzie pełnego i bezwarunkowego zaangażowania się weń ogółu społeczeństwa zapatrzonego w swego wodza, który miał „mieć zawsze rację”. Faszyzm miał być przecież - dodajmy - według jego twórców przejawem wszechogarniającego „działania i uczucia” (azione e sentimento). Jak w swym pierwszym artykule opublikowanym we wrocławskich „Studiach”, tak i w tej rozprawie odniósł się także do ideologicznych uwarunkowań faszyzmu w Italii, powtarzając wcześniej wyrażony pogląd, że głównym zadaniem tej doktryny było „mistyfikowanie rzeczywistych, klasowych funkcji państwa faszystowskiego i racjonalizowanie jego przeobrażeń w kierunku totalitarno-korporacyjnym"'. Wskazał zatem — sięgając do niektórych założeń metodologii tak zwanego naukowego socjalizmu — na służebną rolę ideologii i opartej na niej propagandy faszystowskiej (nadbudowa) wobec Duce i jego rozległego aparatu władzy politycznej (baza). Jak się wydaje, bardziej niż w pierwszym artykule na łamach tego periodyku akcentował w tym tekście znaczenie doktryny w kształtowaniu się faszystowskich stosunków politycznych i społecznych, nie przeceniając wszakże jej wpływu na ustrój ówczes-

8 Odsyłamy także do prac wymienionych już polskich badaczy włoskiego faszyzmu prócz W. Kozuba-Ciembroniewicza: S. Sierpowskiego, Faszyzm we Włoszech 1919-1926 (Wrocław 1973); J.W. Borejszy, Mussolini byt pierwszy... (Warszaw 1989); J.W. Borejszy, Szkoły nienawiści. Historia faszyzmów europejskich 1919-1945 (Wrocław 2000).

9 W. Kozub, Faszyzm we Włoszech 1925-1939. Analiza doktrynalno-ustrojowa, SnFiZH 7, 1981, s. 27. 
nych Włoch. Na marginesie: podobnie rzecz się miała z ideologią nazistowską w Niemczech czy komunistyczną w ZSRR. Nie ulega wątpliwości, że już w artykule z 1981 roku Kozub-Ciembroniewicz dał się poznać jako wytrawny badacz problematyki faszyzmu, choć ulegający wpływom marksistowsko-leninowskiej interpretacji historii jako wyrazu walki klas. Na szczęście nie okazały się one tak silne, by przesłonić mu w miarę obiektywny ogląd rzeczonej problematyki.

Do tematyki tego ciekawego opracowania Kozub-Ciembroniewicz (nadal występujący tylko pod nazwiskiem Kozub) nawiązał w artykule z następnego roku. Analizując w nim funkcje polityczne ideologii faszystowskiej, wskazał na propagandową rolę tworzenia politycznych wyobrażeń symbolicznych, $w$ tym zwłaszcza mitu wspaniałego włoskiego narodu jako spadkobiercy dawnego imperium rzymskiego (Italianitá) na czele z jego „ucieleśnieniem” w osobie Duce, których celem było wpojenie społeczeństwu Italii przekonania o cywilizacyjnym posłannictwie i misji dziejowej tego państwa w basenie Morza Śródziemnego (mare nostrum) ${ }^{10}$. Dążenie do mitologizacji spraw politycznych i społecznych — nierzadko opartej na celowej mistyfikacji sfer życia publicznego, które miały ulec rewolucyjnym przeobrażeniom zmierzającym do stworzenia nowego typu człowieka faszystowskiego, kierującego się zawołaniem „wierzyć, być posłusznym, walczyć” — Kozub uznał za cechy konstytutywne faszyzmu we Włoszech. Na odnośnych doświadczeniach propagandowych w państwie Mussoliniego przynajmniej częściowo wzorowali się - jak trafnie dostrzegł autor - niemieccy naziści po objęciu władzy w 1933 roku. Przypomnijmy, że o ile włoscy faszyści do rangi absolutu podnosili instytucję państwa totalnego, bynajmniej nie podważając znaczenia czynnika narodowego, a nawet nacjonalizmu oraz imperializmu — o tyle narodowi socjaliści za naczelną wartość uważali niemiecką wspólnotę narodową (deutsche Volksgemein$s c h a f t$ ), uznając w swej ideologii państwo jedynie za środek do realizacji interesów owej zbiorowości. W praktyce faszyzm i nazizm w zasadzie nie różniły się jednak między sobą w kwestii ujmowania zadań państwa i zasad jego funkcjonowania. Co jeszcze się tyczy omawianego artykułu: z rozważań krakowskiego uczonego wyłania się antyindywidualistyczny, antyliberalny, antydemokratyczny i antysocjalistyczny oraz kolektywistyczny i totalitarny charakter doktryny faszystowskiej i w ogóle całego systemu faszystowskiego. Dla Kozuba było wtedy oczywiste, że służyły one „w jaskrawy sposób celom i interesom klas posiadających” i dążyły do ,zakamuflowania rzeczywistych, a więc klasowo zdeterminowanych funkcji społecznych"11. Według niego głównie z tych względów mieli faszyści podjąć się budowy systemu korporacyjnego, aby przez zastosowanie tego „społecznego eksperymentu", budzącego zresztą niemałe zainteresowanie elit europejskich w latach dwudziestych i trzydziestych ubiegłego stulecia, móc podporządkować sobie proletariat $\mathrm{i}$ innych najemnych pracowników w imię zasad solidaryzmu i bezkonflik-

10 W. Kozub, Funkcje polityczne ideologii faszystowskiej we Włoszech w latach 1926-1938, SnFiZH 8, 1982, s. 33 n.

11 Ibidem, s. 52. 
towego współdziałania dla dobra ogółu Włochów. W ten sposób zamierzali nie dopuścić do ewentualnego wybuchu w Italii rewolucji robotniczej, która mogłaby się wzorować — czego się obawiano — na rewolucji w Rosji w 1917 roku czy w Niemczech w latach 1918-1919.

Problematyka faszystowskiego korporacjonizmu okazała się tak interesująca dla Wiesława Kozuba-Ciembroniewicza, że poświęcił jej osobny artykuł w tomie wrocławskich „Studiów” z 1985 roku. Za zadanie postawił sobie porównanie założeń tego ustroju z dotyczącą również korporacjonizmu encykliką papieża Piusa XI Quadragesimo anno z 1931 roku $^{12}$. Dość szczegółowo opisując jego wersję faszystowską (przez analizę najważniejszych aktów normatywnych dotyczących korporacjonizmu z Kartą pracy z 1926 roku oraz poglądów faszystowskich ideologów), doszedł do wniosku, że zrzeszające zarówno pracowników, jak i pracodawców syndykaty „,w instytucjonalny sposób miały gwarantować przestrzeganie pluralizmu społeczno-zawodowych interesów, co sprzyjało propagowaniu demagogicznej frazeologii ekonomicznej i socjalnej". Mniej więcej w tym samym czasie kształtujące się korporacyjne koncepcje papieskie wychodziły — podobnie jak doktryna faszystowska - z antyliberalnych i antysocjalistycznych oraz solidarystycznych założeń ideowych. Na tym kończyły się jednak analogie między tymi dwoma ujęciami korporacjonizmu. Jego katolicka wizja, wsparta na obcej faszystom filozofii personalistycznej, nie miała bowiem zasadniczo nic wspólnego z totalitarnym modelem państwa typowym dla faszyzmu. Mussolini i inni faszystowscy teoretycy korporacjonizmu przypisywali - jak twierdził krakowski badacz - aparatowi władzy państwowej rolę czynnika decydującego o wszystkich sprawach dotyczących funkcjonowania struktur stanowo-zawodowych. Byli więc zwolennikami jak najdalej idącej ,statalizacji” korporacji, która wyrażała się w pełnej kontroli tych instytucji przez faszystowskie państwo. Pius XI opowiadał się natomiast za takim ustrojem politycznym, w którym korporacje zachowałyby własną autonomię, a państwo udzielałoby im jedynie niezbędnej pomocy i otaczało je opieką prawną ${ }^{13}$. Zachowując sporą niezależność od państwa, korporacje powinny zatem dystansować się od bieżącej polityki, dbając przede wszystkim o interesy swych członków, a jednocześnie dążąc do utrzymania pokoju społecznego. W opinii Kozuba-Ciembroniewicza krytyka faszystowskiego korporacjonizmu przez głowę Kościoła katolickiego - dążącego w Italii do porozumienia z faszystami - nie była jednak, ,ani zdecydowana, ani też wyraźnie jednoznaczna”. Autor uznał ją raczej za wyraz „sceptycznej refleksji etyczno-moralnej natury” związanej z „poszukiwaniem rozwiązań sprzyjających realizacji ideału katolickiej sprawiedliwości społecznej"14.

12 W. Kozub-Ciembroniewicz, Korporacjonizm Włoch faszystowskich a idee korporacyjne encykliki „Quadragesimo anno”, SnFiZH 9, 1985, s. 127 n.

13 Ibidem, s. 131.

14 Ibidem, s. 131-132. 
W omawianym artykule znalazły się także odniesienia do kontrowersyjnej kwestii totalitarnego charakteru ustroju faszystowskiego we Włoszech. Należy zauważyć, że naukowe dyskusje na ten temat toczyły się niemal od czasu zakończenia drugiej wojny światowej, przede wszystkim na Zachodzie. W okresie PRL częściowo zajął się w naszym kraju owym problemem w zasadzie tylko Franciszek Ryszka, który specjalizował się w nazistowskim totalitaryzmie, w ogóle nie podejmując w swych publikacjach sprawy totalitarnego charakteru ustroju sowieckiego ${ }^{15}$. Dodajmy, że na jego naukowe zapatrywania w ogóle nie powoływał się Kozub-Ciembroniewicz w swym artykule. Wskazał on natomiast w tym kontekście na poglądy Hannah Arendt i Carla J. Friedricha, wprawdzie niezupełnie odmiennie, lecz jednak nieco inaczej ujmujących i kwalifikujących zespół cech składających się na faszystowski system polityczny i społeczny. Przypomnijmy, że Arendt nie uznawała faszystowskich Włoch za państwo w pełni totalitarne w odróżnieniu od Trzeciej Rzeszy i Związku Sowieckiego ${ }^{16}$. Dostrzegała w nim jednak pewne wspólne cechy z tymi dwoma państwami. Według drugiego z wymienionych uczonych (oraz Zbigniewa Brzezińskiego) powinno się natomiast bez zastrzeżeń określać Italię pod rządami Mussoliniego mianem państwa totalitarnego ${ }^{17}$. W omawianym artykule Kozub-Ciembroniewicz nie zajął wyraźnego stanowiska w tej istotnej kwestii badawczej. Bardziej przychylał się jednak — jak się wydaje - do poglądów Friedricha i Brzezińskiego niż Arendt. Takie podejście do tego kontrowersyjnego zagadnienia było zresztą zgodne z przyjętymi przez Kozuba-Ciembroniewicza już we wcześniejszych publikacjach założeniami merytorycznymi. Innymi słowy ujmowanie faszyzmu we Włoszech w kategoriach państwa totalitarnego ułatwiało mu formułowanie naukowych ocen tego zjawiska ${ }^{18}$. $\mathrm{Z}$ tej perspektywy badawczej odniósł się on do również budzącej pewne spory naukowe kwestii antysemityzmu i rasizmu faszystów ${ }^{19}$. W opinii krakowskiego uczonego ich, niezupełnie zresztą autentyczna, wrogość do Żydów - wyrażająca się w prawnych i innych formach prześladowania tej ludności od końca lat trzydziestych minionego stulecia — była pochodną rosnącej zależności ówczesnej Italii od Trzeciej Rzeszy. Antysemickie hasła i działalność z reguły szły w parze

15 Odsyłamy do książki F. Ryszki, Państwo stanu wyjątkowego. Rzecz o systemie państwa i prawa Trzeciej Rzeszy, Wrocław 1986 (i in. wyd.). Ryszka był przeciwny uznawaniu ZSRR za państwo totalitarne. Oficjalnie nie mógłby zresztą w tamtym okresie głosić takiej tezy.

${ }^{16}$ H. Arendt, Korzenie totalitaryzmu, przeł. M. Szawiel i D. Grinberg, Warszawa 1993 (także 2008).

17 C.J. Friedrich, Z. Brzezinski, Totalitarian Dictatorship and Autocracy, New York 1956, s. 52-53 n. Dwa lata wcześniej Friedrich opublikował książkę Totalitarianism (Cambridge 1954).

18 Potwierdzeniem tej tezy może być lektura jego artykułu Władza totalitarna a model państwa prawnego, SnFiZH 23, 2002, s. 45 n. Choć nie dotyczy on tylko włoskiego faszyzmu, wyraźnie wskazuje jednak na zasadnicze odmienności tego ustroju — podobnie jak ustroju Trzeciej Rzeszy i ZSRR — od założeń państwa prawnego, właśnie z powodu jego totalitarnego charakteru.

19 W. Kozub-Ciembroniewicz, Żydzi w doktrynie wtoskiego faszyzmu na tle Manifesto degli scienziati razzisti z 14 lipca 1938 roku, SnFiZH 15, 1992, s. 35 n. 
z forsowaniem przez faszystów w tamtym okresie sztucznej koncepcji odrębnej i wyjątkowej rasy włoskiej o cechach aryjskich. Opisując niektóre przejawy antysemityzmu i rasizmu faszystowskiego we Włoszech, Kozub-Ciembroniewicz trafnie zauważył, że stanowiły one „,istotnie złagodzoną formę hitlerowskiego wzorca". Warto nadmienić, że bardziej dogłębnie od tego badacza podszedł na łamach wrocławskich „Studiów” już w XXI wieku do kwestii żydowskiej w Italii pod rządami Mussoliniego wspomniany Piotr Podemski ${ }^{20}$.

Osobną grupę artykułów opublikowanych przez Wiesława Kozuba-Ciembroniewicza w „Studiach”, liczącą siedem naukowo ważnych tekstów, tworzą rozprawy na temat poglądów poszczególnych twórców ideologii faszystowskiej. Krakowski badacz dał się w nich poznać nie tylko jako wytrawny znawca doktrynalnych podstaw tego totalitaryzmu, lecz także jako doświadczony historyk w ogóle nowszej myśli politycznej i prawnej. Nie od rzeczy będzie wskazać, że jej pełnymi zawiłości, wielotorowymi dziejami zajmował się on i jako uczony, i jako dydaktyk przez wiele lat swojej akademickiej kariery ${ }^{21}$. Jak już zaznaczyliśmy, artykuły Kozuba-Ciembroniewicza o ideologach włoskiego faszyzmu często miały pionierski charakter w polskiej literaturze naukowej. W zasadzie żaden inny rodzimy autor przed tym badaczem nie zajmował się tak szeroko jak on analizą doktryny faszystowskiej w ujęciu jej poszczególnych przedstawicieli. Tym bardziej cenne i pouczające były i są nadal dla czytelnika wyniki odnośnych ustaleń naukowych Kozuba-Ciembroniewicza, ogłaszane drukiem nie tylko na łamach „Studiów nad Faszyzmem i Zbrodniami Hitlerowskimi”. W piśmie tym przedstawił rezultaty swych badań nad koncepcjami politycznymi tylko pięciu ideologów faszystowskich, uważanych jednak za jednych z głównych, jeśli nie najważniejszych twórców tej doktryny. Przypomnienie naukowych osiągnięć krakowskiego uczonego w tej dziedzinie rozpoczniemy od omówienia jego dwóch artykułów dotyczących poglądów Mussoliniego, który uchodził w faszystowskiej Italii za wyrocznię w kwestiach ideologicznych, samemu zresztą kreując się na męża opatrznościowego, podobnie jak Adolf Hitler w Trzeciej Rzeszy czy Józef Stalin w Związku Sowieckim. Pierwszy artykuł Kozuba-Ciembroniewicza o Duce odnosił się do jego interpretacji — jednej z bardzo wielu w historii politycznego piśmiennictwa - kontrowersyjnego dzieła Machiavellego Książe (Il Principe) ${ }^{22}$. Jak już wspomnieliśmy, włoscy faszyści uważali tego florenckiego myśliciela i polityka sprzed pięciuset lat za jednego z prekursorów swojej doktryny. W 1924 roku

20 Zob. dwa artykuły tego autora w „Studiach nad Autorytaryzmem i Totalitaryzmem”: Faszyzm włoski wobec kwestii żydowskiej 1919-1938 (34, 2012, nr 1, s. 81 n.), Prawna i faktyczna sytuacja włoskich Żydów w dobie prześladowań faszystowskich 1938-1943 (35, 2013, nr 3, s. 7 n.).

21 W. Kozub-Ciembroniewicz był współautorem i współredaktorem dwóch obszernych opracowań podręcznikowych z tej dziedziny: Doktryny polityczne XIX i XX wieku (Kraków 2000), Wspótczesne doktryny polityczne i prawne. Twórcy, idee, interpretacje (Kraków 2012).

22 W. Kozub-Ciembroniewicz, Makiawelowski Książę w interpretacji Benito Mussoliniego, SnFiZH 11, 1987, s. 55 n. 
wstęp do Księcia Machiavellego napisał Mussolini w formie aktualnego politycznie komentarza ideologicznego do burzliwej sytuacji po wyborach parlamentarnych w Italii w tym samym roku. Duce uznał siebie w tym wstępie za godnego następcę makiawelowskiego modelu księcia o cechach nowoczesnego dyktatora, a nawet za jego szczególne uosobienie. W opinii krakowskiego badacza Mussolini starał się przedstawić jako kontynuator i realizator wyrażonej w dziele florenckiego myśliciela koncepcji apologii państwa i jego silnej władzy. W na ogół niezgodnych z moralnością zasadach polityki uprawianej przez księcia (według zaleceń Machiavellego) miał upatrywać urzeczywistnienie reguł obowiązujących w warunkach „stanu wyjątkowego", które usprawiedliwiały stosowanie rozmaitych metod - włącznie z użyciem siły, przemocy i terroru — służących do osiągnięcia nadrzędnych celów ${ }^{23}$. Jak trafnie zauważył Kozub-Ciembroniewicz, Duce, sytuując się w roli księcia-dyktatora i posługując się ideą predestynacji, zamierzał w ten sposób uzasadnić swoje wodzowskie aspiracje jako niezbędne do przebudowy stosunków politycznych i społecznych w duchu faszystowskim.

Rozwinięcie Mussoliniego koncepcji władzy, państwa i społeczeństwa nastąpiło kilka lat po napisaniu przez niego wstępu do dzieła Machiavellego - w rozprawie Doktryna faszyzmu (La dottrina del fascismo - 1932 roku) będącej jego manifestem politycznym już jako w pełni dyktatora. Treści tego opracowania dotyczy drugi, niewątpliwie ważny w dorobku naukowym dotyczącym ideologicznej problematyki faszyzmu włoskiego, artykuł krakowskiego uczonego o Duce. Przedstawione w Doktrynie faszyzmu zapatrywania Mussoliniego zostały przez Kozuba-Ciembroniewicza precyzyjnie podzielone na dziesięć grup tematycznych. Kolejno zajął się on omówieniem ujęcia przez Duce kwestii idei i czynu, spirytualizmu, człowieka faszyzmu, religii pozytywnej, apoteozy państwa, osobowości wyższego stopnia, negacji marksizmu, krytyki demokracji, antyliberalizmu i Włoch jako imperialnego mocarstwa. Należy zaznaczyć, że wnikliwe wywody na temat każdego z tych — składających się na kwintesencję światopoglądu Mussoliniego, a przez niego także innych faszystów — zagadnień oparł na dogłębnej analizie materiału źródłowego. Ze względu na znaczną objętość rzeczonego artykułu nie będziemy szerzej omawiać poszczególnych, zapewne trafnych ustaleń naukowych krakowskiego badacza. Wiele interesujących spostrzeżeń na temat cech doktryny faszystowskiej zawarł on już w swych wcześniejszych, wskazanych przez nas publikacjach na łamach „Studiów”. Warto natomiast odnieść się do treści zakończenia artykułu o tym według Kozuba-Ciembroniewicza „podstawowym dokumencie ideologicznym systemu faszystowskiego". Autor nie dokonał w nim podsumowania swych rozważań o doktrynie Mussoliniego, lecz jedynie zwrócił uwagę na brak w jego rozprawie wyraźnych akcentów antysemickich i rasistowskich.

${ }^{23}$ W tym kontekście Kozub-Ciembroniewicz odwołał się do koncepcji stanu wyjątkowego w powiązaniu z ideą suwerenności - niemieckiego prawnika C. Schmitta, wyrażonej przez niego między innymi w pracy Soziologie des Souverenitätsbegriffes und politische Theologie (München 1923). 
Jak wiadomo, pojawiły się one — pod wpływem odnośnych rozwiązań prawnych $\mathrm{w}$ Niemczech nazistowskich - w ideologii, propagandzie i polityce włoskiego faszyzmu dopiero bliżej końca lat trzydziestych. Krakowski badacz uznał pracę Doktryna faszyzmu nie tylko za wolną od „skrajnego radykalizmu” charakterystycznego dla koncepcji Hitlera i innych nazistów odnoszących się z nienawiścią do Żydów i wszelkich rasowo „obcych” grup lub narodów, ale także w swej wymowie za „konserwatywną” i noszącą cechy „wykładu akademickiego"24. Znamienne, że opinię tę oparł na tezach naukowych głoszonych przed wielu laty przez skądinąd wybitnego niemieckiego historyka Ernsta Noltego, uważanego jednak w wielu środowiskach akademickich (między innymi w PRL) za raczej kontrowersyjnego uczonego ${ }^{25}$.

Wiesław Kozub-Ciembroniewicz podzielił się z czytelnikami wrocławskich „Studiów” również rezultatami swych badań nad politycznymi koncepcjami jeszcze pięciu innych — prócz Mussoliniego — ideologów faszystowskich. W dwóch artykułach poddał naukowej analizie zapatrywania Giovanniego Gentile, uważanego w międzywojennych Włoszech za jeden z głównych intelektualnych „mózgów" ówczesnego reżimu państwowego, głosiciela tak zwanego aktualizmu filozoficznego opartego na poglądach Georga Wilhelma Friedricha Hegla i Johanna Gottlieba Fichtego. W pierwszym tekście o Gentilem krakowskich uczony za temat rozważań przyjął zestawienie z sobą jego faszystowskiego manifestu (Manifesto degli intellettuali fascisti agli intelletuali di tutte le nazioni) z 21 kwietnia 1925 roku z szybką odpowiedzią na ten propagandowy dokument ze strony wybitnego myśliciela liberalnego, także zresztą odwołującego się do Hegla - Benedetto Crocego (30 kwietnia 1925 roku) ${ }^{26}$. Według Kozuba-Ciembroniewicza Gentile podjął się w swym manifeście postracjonalizacji wydarzeń politycznych prowadzących na początku 1925 roku do ostatecznego ukształtowania się dyktatury Mussoliniego i rozbudowy ustroju faszystowskiego. Faszystowski ideolog usiłował nadać dokonującym się wówczas przeobrażeniom w swym kraju charakter „drugiego Risorgimento", czyli nowej walki o utrwalanie wielkości Italii, prowadzonej tym razem przez Duce i jego popleczników. W manifeście Gentilego znalazł się również postulat uczynienia wszystkiego gwoli upowszechnienia faszystowskiego światopoglądu jako podstawy stworzenia „nowego typu włoskiego obywatela”. Temu celowi miało służyć zasadnicze ograniczenie wolności słowa i prasy oraz propagandowe zwalczanie „demoliberalizmu”. Postulaty Gentilego spotkały się z ostrą krytyką

24 W. Kozub-Ciembroniewicz, „Doktryna faszyzmu” Benita Mussoliniego, SnFiZH 24, 1991, s. $47 \mathrm{n}$.

${ }^{25}$ Chodzi o pracę E. Noltego, Der Faschismus in seiner Epoche. Die Action française. Der italienische Faschismus. Der Nationalsozialismus, München 1971 (i in. wyd.). Dodajmy, że Nolte zasłynął w latach osiemdziesiątych ubiegłego wieku również jako kontrowersyjny uczestnik tak zwanego sporu historyków (Historikerstreit) na temat wyjątkowości zbrodni nazistowskich na tle innych systemów totalitarnych.

26 W. Kozub-Ciembroniewicz, Manifest faszystowski Giovanniego Gentile i protest Benedetto Crocego, SnFiZH 10, 1986, s. 179 n. 
ze strony przeciwnika faszyzmu Crocego (Risposta al Manifesto degli intellettuali fascisti). Ten wybitny uczony nie pozostawił „suchej nitki” na wywodach faszystowskiego intelektualisty. Reprezentowaną przez niego i jemu podobny propagandystów ideologię uznał za „,inkoherentny i antykulturowy wytwór demagogii, mistycyzmu i cynizmu o tendencjach absolutystycznych"27. Jako zdeklarowany obrońca liberalnej demokracji Croce po kolei rozprawił się ze wszystkimi tezami Gentilego. Faszystom zarzucił zwłaszcza zdradę ideałów Risorgimento oraz wypaczenie zasad korporacjonizmu ${ }^{28}$. Jak już wspomnieliśmy, Kozub-Ciembroniewicz opublikował we wrocławskich „Studiach” jeszcze jeden artykuł o Gentilem. Tekst ten został częściowo oparty na analizie jego manifestu faszystowskiego z 1925 roku, a częściowo - na późniejszych rozprawach tego intelektualisty z opracowaniem Origini e dottrina del fascismo (1929). Ograniczymy się zatem do wskazania na najważniejsze elementy światopoglądu Gentilego. Prócz idei neoheglizmu, aktualizmu i Risorgimento składały się nań filozofia czynu, wola konkretna oraz duch opatrznościowy. Wszystko to w większym bądź mniejszym stopniu odnosiło się do samego Mussoliniego jako wodza, tworząc jednocześnie podstawy budowy faszystowskiego „państwa etycznego" 29 .

W drugiej połowie lat dziewięćdziesiątych ubiegłego wieku ukazały się w „Studiach” cztery artykuły uczonego o kolejnych czterech intelektualistach faszystowskich. Listę tę otwierał tekst opublikowany jeszcze w 1994 roku o twórcy - jak to określił Kozub-Ciembroniewicz - ideologii elitarystyczno-korporacyjnej: Guido Bortolotto ${ }^{30}$. Według autora była ona swoistym konglomeratem dwóch zasad, elitaryzmu i korporacjonizmu, które zostały następnie wzbogacone koncepcjami predestynacji wodza, inwestytury partii, nacjonalizmu, solidaryzmu oraz przyjęciem totalitarnego modelu władzy. W efekcie w ideologii tej miały wybijać się na pierwszy plan „silnie akcentowany antyindywidualizm” (powiązany z koncepcją mas społecznych) oraz negowanie rozwiązań ustrojowych typowych dla myśli liberalno-demokratycznej. Jak z pewnym przejaskrawieniem podkreślił Kozub-Ciembroniewicz: „Bortolotto odrzucił tradycje i doświadczenie cywilizacji prawno-politycznej wyrosłej z prawa natury oraz racjonalistycznej filozofii, opowiadając się po stronie skrajnej reakcji” ${ }^{31}$. Zauważył też, że badanie przez Bortolottego relacji zachodzących między wodzem, elitą a masami w ścisłym kontekście nacjonalistycznym i solidarystycznym doprowadziło go do wypracowania organicystycznego sposobu pojmowania narodu i systemu korporacyjnego. Jednak,

27 Ibidem, s. 189-190.

28 Warto dodać, że wspomniana uczennica prof. Kozuba-Ciembroniewicza M. Kiwior-Filo poświęciła poglądom Crocego sporo swoich publikacji, w tym monografię Myśl polityczna włoskich liberałów wobec faszyzmu (Kraków 2013).

29 W. Kozub-Ciembroniewicz, Państwo etyczne Giovanniego Gentile, SnFiZH 20, 1997, s. $211 \mathrm{n}$.

30 W. Kozub-Ciembroniewicz, Wódz, elita, masy w ideologii Guida Bortolotto, SnFiZH 17, 1994, s. 75 n.

31 Ibidem, s. 87. 
ze względu na mocny totalitarny rys przedstawionego modelu władzy zarówno korporacjonizm, jak i szerzej organicyzm Bortolotto, były w opinii krakowskiego uczonego wyraźnie odmienne od konserwatywnego paradygmatu.

Kolejny artykuł z tej grupy poświęcony został profesorowi politologii - Sergiowi Panunzio, autorowi rozprawy z początku lat trzydziestych XX wieku na temat ogólnej nauki o państwie faszystowskim. Pod pewnymi względami jego koncepcje polityczne różniły się od teorii aktualizmu Gentilego, choć wyrastały ze zbliżonych przesłanek doktrynalnych. $Z$ dokonanej przez Kozuba-Ciembroniewicza wnikliwej analizy koncepcji Panunzia wyłania się całkowita apologia tego państwa, którego totalitarną istotę miał najlepiej ująć sam Mussolini w słowach: „wszystko w państwie, nic bez państwa, nic przeciwko państwu”32. W odnośnych poglądach ten faszystowski intelektualista nie był jednak absolutnym totalitarystą. Uzasadnienia swojej wizji państwa poszukiwał między innymi w filozofii politycznej Thomasa Hobbesa (państwo jako Lewiatan), odrzucając wszelkie idee suwerenności ludu, formułowane zwłaszcza przez Jean-Jacques’a Rousseau. Dla Panunzia państwo faszystowskie jawiło się jako twór monopartyjny i syndykalistyczny, typowy dla nowego w dziejach ,okresu organicznego”, który zrywał z ustrojowymi rozwiązaniami tak liberalnymi, jak i socjalistycznymi. Faszyzm stanowił dla tego intelektualisty przejaw „rewolucji konserwatywnej”, która z jednej strony opierała się na idei gwałtownych przeobrażeń, z drugiej zaś — kultywowała niektóre tradycyjne wartości i instytucje (między innymi rodzinę) $)^{33}$.

Do rozwoju ideologii faszystowskiej przyczynił się także badacz dziejów średniowiecza Gioacchino Volpe. Zgodnie ze swoją profesją rozpatrywał on powstanie i rozwój faszyzmu w Italii w kategoriach historiozoficznych, wskazując zwłaszcza na rolę „rewolucji narodowej” dokonującej się w tym państwie za sprawą charyzmatycznego przywództwa Mussoliniego i jego partyjnych towarzyszy ${ }^{34}$. Z wywodów Kozuba-Ciembroniewicza wynika, że Volpe skupił się na problemie „nowego ustroju” Włoch pod rządami faszystów. Do jego najbardziej charakterystycznych cech zaliczył ewidentną nadrzędność władzy wykonawczej nad władzą ustawodawczą, upatrując źródeł tej hegemonii w szczególnej pozycji ustrojowej Duce. Warto zaznaczyć, że autor omawianego artykułu określił polityczny program Volpego jako konserwatywny nacjonalizm wzbogacony o wątki socjalne.

Przedmiotem ostatniej rozprawy Kozuba-Ciembroniewicza w grupie tekstów o ideologach faszystowskich był artykuł o profesorze prawa Alfredzie Rocco, który

32 W. Kozub-Ciembroniewicz, Państwo faszystowskie w interpretacji Sergio Panunzio, SnFiZH 19, 1996, s. 76.

33 Koncepcje rewolucyjne konserwatyzmu szczególnie rozwinęły się po pierwszej wojnie światowej w Niemczech jako ideologia antydemokratyczna i antyliberalna oraz autorytarna, nawiązująca zresztą do doktryny włoskiego faszyzmu. Więcej o tym por. M. Maciejewski, Niemieckie elity a hitleryzm. O stosunku rewolucyjnych konserwatystów do nazizmu w Rzeszy republikańskiej i hitlerowskiej, Wrocław 1994, passim.

34 W. Kozub-Ciembroniewicz, Faszyzm a historia wedlug Gioacchina Volpego, SnFiZH 21, 1998, s. $21 \mathrm{n}$. 
był jednym z głównych twórców tej doktryny. Jej założenia wyłożył on już około połowy lat dwudziestych minionego stulecia. Krakowski badacz skupił swoje rozważania o Rocco przede wszystkim na jego krytyce demoliberalizmu. Wychodząc z takich założeń ideowych jak antyindywidualizm i antyprogresywizm, nakreślił on ,pozytywny” obraz faszyzmu, na który miały się składać następujące elementy: działanie i uczucie, organiczność, integralność, cnota rewolucyjna, doskonałość, oryginalność, ludowość/narodowość, wodzostwo, elitaryzm czy arbitralność ${ }^{35}$. Każdy z nich przekładał się — według Rocco — na konkretne rozwiązania ustrojowo-prawne podejmowane w ówczesnej Italii w celu jej „,wielkiej przebudowy w duchu faszystowskim". Jak poglądy omówionych już ideologów faszyzmu, tak i koncepcje tego intelektualisty, bynajmniej niepozbawione cech zwartego systemu myślowego, służyły przede wszystkim propagowaniu założeń tego ustroju społeczno-politycznego. Dobitnie potwierdza to lektura artykułów Kozuba-Ciembroniewicza.

Jak wcześniej wspomnieliśmy, trzecią grupę artykułów Kozuba-Ciembroniewicza na łamach wrocławskich „Studiów” tworzą teksty, które bardziej luźno związane były z głównym nurtem jego zainteresowań badawczych. Przeważały zdecydowanie wśród nich artykuły omawiające doktrynę faszystowską z punktu widzenia jej krytyków i przeciwników politycznych, a także jej badaczy. Pierwszy z tego cyklu tekst ${ }^{36}$ poświęcony został koncepcji genezy faszyzmu wyłożonej przez współtwórcę Włoskiej Partii Socjalistycznej Filippa Turatiego w powstałej w 1928 roku pracy zatytułowanej Fascismo, socialismo e democrazia ${ }^{37}$. Była to jak celnie to ujął Kozub-Ciembroniewicz - swoista ekspertyza ideowo-polityczna i socjohistoryczna faszyzmu. Zdaniem krakowskiego naukowca Turati „traktowal faszyzm jako zjawisko patologiczne, europejskie i historyczne, uwarunkowane klasowo, społeczno-ekonomicznie, psychologicznie oraz ideowo-politycznie"38, które swe korzenie miało w będącym pokłosiem wojny światowej kryzysie demokracji i parlamentaryzmu, we wzroście nastrojów rewolucyjnych, w dążeniach do realizacji swoich interesów przez wielką burżuazję oraz $\mathrm{w}$ specyficznym stanie świadomości ,zdeklasowanych warstw społecznych”. Trafnie wskazując na reformistyczne i niechętne rewolucyjnemu bolszewizmowi nastawienie polityczne Turatiego ${ }^{39}$, Kozub-Ciembroniewicz wyłożył pogląd, że najbardziej oryginalnym

35 W. Kozub-Ciembroniewicz, Faszyzm wobec demoliberalizmu wedtug Alfreda Rocco, SnFiZH 22, 1999, s. 115 n.

36 W. Kozub-Ciembroniewicz, Geneza faszyzmu w ideologii Filippo Turatiego, SnFiZH 12, 1987, s. 73 n.

37 Dokument ten był cytowany przez Kozuba-Ciembroniewicza za pośrednictwem tłumaczenia na język niemiecki zawartego w opracowanej przez publikującego na łamach SnFiZH kontrowersyjnego historyka Ernsta Noltego antologii pt. Theorien über den Faschismus (Köln-Berlin 1967, s. 143-155).

38 W. Kozub-Ciembroniewicz, Geneza faszyzmu w ideologii Filippo Turatiego, s. 84.

39 Omówieniu zmiennych i niejednorodnych postaw włoskich socjalistów i komunistów wobec doktryny i praktyki państwa Mussoliniego Kozub-Ciembroniewicz poświęcił artykuł pt. Le- 
elementem koncepcji tego włoskiego socjalisty był postulat przeciwstawienia się faszyzmowi „w skali międzynarodowej”, gdyż nieuchronnym skutkiem rozwoju tego systemu politycznego miała być nowa wojna światowa zdolna do zniszczenia cywilizacji europejskiej.

Wśród włoskich przeciwników faszyzmu znajdowali się nie tylko socjaliści pokroju Turatiego. Liczne i intelektualnie wpływowe grono antyfaszystowskie wywodziło się z kręgów zbliżonych do założyciela Włoskiej Partii Ludowej (włoskiej chadecji) Luigiego Sturza. Poglądom tego księdza i kluczowego aktora włoskiej sceny politycznej Kozub-Ciembroniewicz poświecił artykuł otwierający pierwszy tom „Studiów nad Faszyzmem i Zbrodniami Hitlerowskimi”, który ukazał się już w Polsce uwolnionej od istnienia zinstytucjonalizowanej cenzury ${ }^{40}$. Krakowski doktrynolog podkreślił, że Sturzo w sposób zasadniczy odrzucił metodę siłowej walki z reżimem Mussoliniego, wierząc w możliwość odtworzenia we Włoszech demokracji i wolności dzięki sile antyfaszystowskich idei, które w szczególności rozwijane byłyby na fundamencie argumentów moralnych, kulturowych i ekonomicznych. System polityczny powstały we Włoszech po marszu na Rzym Sturzo określał mianem konserwatywnej dyktatury o totalitarnym charakterze, gdyż jej elementem konstytutywnym był specyficzny dualizm łączący tradycyjne instytucje wyrosłe z porządku konstytucyjnego i prawnego (takie jak monarchia, parlament czy armia), z nowymi instytucjami, takimi jak wódz, partia wodzowska czy milicja faszystowska, które się opierały na rewolucyjnej przemocy. Ciekawym spostrzeżeniem Kozuba-Ciembroniewicza poczynionym na kanwie tezy Sturza o dualistycznym charakterze państwa Mussoliniego było przypisanie temu włoskiemu chadekowi posługiwania się metodologicznym funkcjonalizmem przejawiającym się w rozpatrywaniu zjawisk politycznych w bezpośrednim związku z ich funkcją społeczną. Kozub-Ciembroniewicz zauważył, że Sturzo trafnie wskazał, że mimo pewnej atrakcyjności eksperymentu społeczno-gospodarczego budowanego w ramach państwa faszystowskiego model ten nie może być skutecznie przeszczepiony do innych krajów i nie stanie się podstawą do budowy zwartej międzynarodówki faszystowskiej. Jego cechą był bowiem swoisty egoizm narodowy, który z samej swej natury nie może być płaszczyzną międzynarodowego porozumienia.

Ważną częścią okołofaszystowskich zainteresowań naukowych Kozuba-Ciembroniewicza były badania nad polską refleksją nad zjawiskiem faszyzmu, czy też szerzej to ujmując: fenomenem totalitaryzmu. Ich przejawem był nie tylko jego aktywny udział we wspomnianym na początku artykułu grancie dotyczącym próby opisania zjawiska totalitaryzmu od strony prawnej, lecz także opracowanie kilku interesujących tekstów, z których pięć opublikowano na łamach „Studiów

wica wtoska wobec faszyzmu w latach 1926-1938 opublikowany w tomie szesnastym SnFiZH (1993), s. 123 n.

40 W. Kozub-Ciembroniewicz, Faszyzm, antyfaszyzm, demokracja w refleksji politycznej Luigi Sturzo, SnFiZH 13, 1990, s. 3 n. 
nad Faszyzmem i Totalitaryzmem”. Były to artykuły poświęcone kolejno: powstałym w komunistycznej Polsce naukowym ujęciom faszyzmu ${ }^{41}$, różnicom występującym pomiędzy państwem totalitarnym a państwem prawa ${ }^{42}$, wyłożonej przez Konstantego Grzybowskiego analizie przemian ustrojowych w Rosji po przejęciu władzy przez bolszewików ${ }^{43}$, jednej z pierwszych polskich prób zrozumienia fenomenu faszyzmu przedstawionej w przedwojennej Encyklopedii nauk politycz$n y \mathrm{ch}^{44}$ oraz badaniom polityczno-prawnym Franciszka Ryszki nad systemami autorytarnymi i totalitarnymi w dwudziestowiecznej Europie ${ }^{45}$. W każdym z tych tekstów Kozub-Ciembroniewicz w sposób typowy dla swego świetnego stylu pisarskiego efekty wnikliwych analiz badawczych był w stanie przedstawić w słowach oszczędnych i charakteryzujących się neutralnością emocjonalną najwyższej próby. Szczególnie widoczne to było podczas omawiania wyników niezmiernie trudnych (z uwagi na świeżość zjawiska i kwestie personalne) analiz dotyczących poglądów polskich naukowców na faszyzm głoszonych w okresie panowania reżimu komunistycznego. Nie trzeba chyba przecież nikogo dziś przekonywać, że wiele powstałych wówczas tez skażonych było totalitarną abominacją wobec prawdy historycznej, wolności i człowieka. Jednocześnie Kozub-Ciembroniewicz potrafił z wielką skromnością docenić osiągnięcia innych badaczy, wskazując na ich zasługi w rozwoju nauki. Pokazał to chociażby w artykule dotyczącym międzywojennej Encyklopedii nauk politycznych, znakomicie oddając nowatorstwo części zawartych w niej analiz, jak dla przykładu koncepcji Stanisława Wętkiewicza pojmowania państwa Mussoliniego jako swoistego państwa stanu wyjątkowego opierającego swe funkcjonowanie na quasi-religijnym autorytecie wodza albo propozycji Stanisława Swianiewicza, aby badając naturę Trzeciej Rzeszy, zwrócić uwagę na rolę, jaką w sferze gospodarczej w Niemczech Hitlera odgrywały pojęcia Leistung i Leistungswettbewerb.

Profesor Wiesław Kozub-Ciembroniewicz należał — jak zaznaczyliśmy to na początku — do jednych z najczęściej publikujących autorów na łamach „Studiów nad Faszyzmem i Zbrodniami Hitlerowskimi”. Bezsprzecznie związane to było z tym, że poruszane przez niego zagadnienia w polskim obiegu naukowym były nowe lub stosunkowo mało znane. Wysiłek badawczy tego krakowskiego uczonego odcisnął w związku z tym wyraźne piętno nie tylko na jego bezpośrednich uczniach, ale także na szerokich rzeszach polskich badaczy, szczególnie tych

${ }^{41}$ W. Kozub-Ciembroniewicz, Interpretacje faszyzmu w Polsce (1945-1989), SnFiZH 28, 1995, s. 63 n.

42 W. Kozub-Ciembroniewicz, Wtadza totalitarna a model państwa prawnego.

43 W. Kozub-Ciembroniewicz, System sowiecki w analizach Konstantego Grzybowskiego, SnFiZH 25, 2002 s. 123 n.

44 W. Kozub-Ciembroniewicz, Problematyka faszyzmu w międzywojennej Encyklopedii nauk politycznych, SnFiZH 26, 2003, s. $271 \mathrm{n}$.

45 W. Kozub-Ciembroniewicz, Faszyzm i niedemokratyczne systemy władzy w twórczości naukowej Franciszka Ryszki, SnFiZH 27, 2004, s. 389 n. 
o doktrynologicznych i historycznoprawnych inklinacjach. Wierzymy, że spuścizna naukowa profesora Kozuba-Ciembroniewicza jeszcze przez wiele lat będzie inspiracją dla kolejnych pokoleń prawników, politologów i historyków.

\section{Bibliografia}

Arendt H., Korzenie totalitaryzmu, Warszawa 1993 (także 2008).

Bankowicz M., Kozub-Ciembroniewicz W., Dyktatury i tyranie. Szkice o niedemokratycznej władzy, Kraków 2007.

Bartyzel J., ,Umierać, ale powoli”. O monarchistycznej i katolickiej kontrrewolucji w krajach romańskich 1815-2000, Kraków 2002.

Borejsza J.W., Mussolini byt pierwszy..., Warszawa 1989.

Borejsza J.W., Szkoły nienawiści. Historia faszyzmów europejskich 1919-1945, Wrocław 2000.

Eatwell R., Faszyzm. Historia, Poznań 1999.

Foro P., Włochy faszystowskie, Kraków 2008.

Friedrich C.J., Brzezinski Z., Totalitarian Dictatorship and Autocracy, New York 1956.

Gentile E., Początki ideologii faszystowskiej (1918-1925), Warszawa 2011.

Hägg G., Mussolini. Butny faszysta, Warszawa 2015.

Kiwior-Filo M., In memoriam... Profesor Wiesław Kozub-Ciembroniewicz (26 lipca 1944-13 lutego 2015), „Alma Mater. Miesięcznik Uniwersytetu Jagiellońskiego” 2015, nr 173-174.

Kiwior-Filo M., Myśl polityczna włoskich liberatów wobec faszyzmu, Kraków 2013.

Kiwior-Filo M., Profesor Wiesław Kozub-Ciembroniewicz — wspomnienie Mistrza, „Politeja. Pismo Wydziału Studiów Międzynarodowych i Politycznych Uniwersytetu Jagiellońskiego" 2014, nr 6.

Kozub W., Faszyzm we Włoszech 1925-1939. Analiza doktrynalno-ustrojowa, SnFiZH 7, 1981.

Kozub W., Funkcje polityczne ideologii faszystowskiej we Włoszech w latach 1926-1938, SnFiZH 8, 1982.

Kozub W., Podstawy ideologiczne włoskiego faszyzmu, SnFiZH 3, 1977.

Kozub-Ciembroniewicz W., ,Doktryna faszyzmu” Benita Mussoliniego, SnFiZH 14, 1991.

Kozub-Ciembroniewicz W., Doktryna i system Włoch faszystowskich na tle porównawczym, Kraków 2011.

Kozub-Ciembroniewicz W., Doktryny włoskiego faszyzmu i antyfaszyzmu w latach 1922-1939, Kraków 1992.

Kozub-Ciembroniewicz W., Faszyzm, antyfaszyzm, demokracja w refleksji politycznej Luigi Sturzo, SnFiZH 13, 1990.

Kozub-Ciembroniewicz W., Faszyzm a historia wedtug Gioacchina Volpego, SnFiZH 21, 1998, s. 21.

Kozub-Ciembroniewicz W., Faszyzm i niedemokratyczne systemy władzy w twórczości naukowej Franciszka Ryszki, SnFiZH 27, 2004.

Kozub-Ciembroniewicz W., Faszyzm wobec demoliberalizmu wedtug Alfreda Rocco, SnFiZH 22, 1999.

Kozub-Ciembroniewicz W., Geneza faszyzmu w ideologii Filippo Turatiego, SnFiZH 12, 1987.

Kozub-Ciembroniewicz W., Interpretacje faszyzmu w Polsce (1945-1989), SnFiZH 18, 1995.

Kozub-Ciembroniewicz W., Korporacjonizm Włoch faszystowskich a idee korporacyjne encykliki „Quadragesimo anno”, SnFiZH 9, 1985.

Kozub-Ciembroniewicz W., Lewica włoska wobec faszyzmu w latach 1926-1938, SnFiZH 16, 1993.

Kozub-Ciembroniewicz W., Makiawelowski Książę w interpretacji Benito Mussoliniego, SnFiZH 11, 1987.

Studia nad Autorytaryzmem i Totalitaryzmem 41, nr 3, 2019

(C) for this edition by CNS 
Kozub-Ciembroniewicz W., Manifest faszystowski Giovanniego Gentile i protest Benedetto Crocego, SnFiZH 10, 1986.

Kozub-Ciembroniewicz W., Państwo etyczne Giovanniego Gentile, SnFiZH 20, 1997.

Kozub-Ciembroniewicz W., Państwo faszystowskie w interpretacji Sergio Panunzio, SnFiZH 19, 1996.

Kozub-Ciembroniewicz W., Problematyka faszyzmu w międzywojennej Encyklopedii nauk politycznych, SnFiZH 26, 2003, s. 271 n.

Kozub-Ciembroniewicz W., System sowiecki w analizach Konstantego Grzybowskiego, SnFiZH $25,2002$.

Kozub-Ciembroniewicz W., Władza totalitarna a model państwa prawnego, SnFiZH 23, 2002.

Kozub-Ciembroniewicz W., Wódz, elita, masy w ideologii Guida Bortolotto, SnFiZH 14, 1994.

Kozub-Ciembroniewicz W., Żydzi w doktrynie włoskiego faszyzmu na tle Manifesto degli scienziati razzisti z 14 lipca 1938 roku, SnFiZH 15, 1992.

Laqueur W., Faszyzm wczoraj - dziś - jutro, Warszawa 1998.

Maciejewski M., In memoriam... Wiesław Kozub-Ciembroniewicz (1944-2015), „Studia nad Autorytaryzmem i Totalitaryzmem" 36, 2014, $\mathrm{nr} 4$.

Maciejewski M., Niemieckie elity a hitleryzm. O stosunku rewolucyjnych konserwatystów do nazizmu w Rzeszy republikańskiej i hitlerowskiej, Wrocław 1994.

Nolte E., Der Faschismus in seiner Epoche. Die Action française. Der italienische Faschismus. Der Nationalsozialismus, München 1971.

Paxton R.O., Anatomia faszyzmu, Poznań 2005.

Podemski P., Faszyzm włoski wobec kwestii żydowskiej 1919-1938, SnAT 34, 2012, nr 1.

Podemski P., Prawna i faktyczna sytuacja włoskich Żydów w dobie prześladowań faszystowskich 1938-1943, SnAT 35, 2013, nr 3.

Ryszka F., Państwo stanu wyjątkowego. Rzecz o systemie państwa i prawa Trzeciej Rzeszy, Wroclaw 1986.

Schmitt C., Soziologie des Souverenitätsbegriffes und politische Theologie, München 1923.

Sierpowski S., Faszyzm we Włoszech 1919-1926, Wrocław 1973.

Sondel-Cedarmas J., Wspomnienie Profesora Wiesława Kozuba-Ciembroniewicza, SnAT 37, 2015, nr 1.

Theorien über den Faschismus, red. E. Nolte, Köln-Berlin 1967.

Totalitarianism, red. C.J. Friedrich, Cambridge 1954.

Totalitaryzmy XX wieku. Idee - instytucje - interpretacje, red. W. Kozub-Ciembroniewicz, H. Kowalska-Stus, B. Szlachta, M. Kiwior-Filo, Kraków 2010.

Turati F., Faschismus, Sozialismus und Demokratie, [w:] Theorien über den Faschismus, red. E. Nolte, Köln-Berlin 1967.

Wielomski A., Faszyzmy tacińskie. Sen o rewolucji innej niż w Rosji i Niemczech, Biała Podlaska-Warszawa 2011.

Wielomski A., Hiszpania Franco. Źródła i istota doktryny politycznej, Biała Podlaska 2006.

\section{SCHOLARLY PAPERS BY WIESŁAW KOZUB-CIEMBRONIEWICZ IN STUDIES ON FASCISM AND NAZI CRIMES}

\section{Summary}

Professor Wiesław Kozub-Ciembroniewicz was one of the most often published authors in the journal Studies on Fascism and Nazi Crimes. Undoubtedly, it was related to the fact that the issues raised by him were new or relatively little known in Polish scholarly thought. The research effort of this Cracow scholar has left a clear mark not only on his direct pupils and successors but 
also on the vast circle of Polish researchers, especially those with doctrinal and historical-legal inclinations. The Authors believe that the scientific legacy of Professor Kozub-Ciembroniewicz will continue to be an inspiration for successive generations of lawyers, political scientists and historians for many years.

Keywords: totalitarianism, fascism, National Socialism, Kozub-Ciembroniewicz.

\author{
Marek Maciejewski \\ marek.maciejewski@uwr.edu.pl \\ Tomasz Scheffler \\ tomasz.scheffler@uwr.edu.pl
}

